\title{
Удосконалення правових основ державного нагляду за дотриманням орендарями України вимог екологоощадного землекористування та охорони земель
}

\author{
О.В. Овчаров ${ }^{1}$, В.М. Власовець ${ }^{2}$ \\ ${ }^{1}$ Харківський національний університет Повітряних Сил \\ імені Івана Кожедуба (м. Харків, Україна) \\ 2 Харківський національний технічний університет сільського господарства \\ імені Петра Василенка (м. Харків, Україна)
}

\begin{abstract}
Проаналізовано стан землекористування в товарному сільськогосподарському виробництві. Наведено дані суттєвого погіршення кількісних і якісних характеристик сільськогосподарських земель. Зазначено серйозну недосконалість законодавчо-правового супроводу питань оренди земель та державного нагляду за правильністю землекористування. Метою цієї роботи є розробка пропозицій з вдосконалення державного нагляду за виконанням орендарями вимог щодо збереження родючості ґрунтів, в тому числі й за рахунок впровадження науково обґрунтованих законодавчих пропозицій.
\end{abstract}

Ключові слова: державний нагляд (контроль), законодавчо-правовий супровід, Конституція України, чинне законодавство, деградовані землі, гумус, оренда, землевласник, сівозміна, родючість грунтів.

Вступ. Постановка проблеми. Земельний фонд України становить 60,3 млн. га, або близько 6\% території Європи. Сільськогосподарські угіддя складають біля 19\% від загальноєвропейських, у тому числі рілля - $27 \%$. Показник площі цих угідь на одну особу є найвищим серед європейських країн і становить 0,9 га, у тому числі 0,7 га ріллі (середній показник європейських країн - 0,44 і 0,25 гектара відповідно). У цілому площа сільськогосподарських земель складає 42,7 млн. га, або 70\% площі країни, площа ж ріллі - 32,5 млн. га, або 78,4\% усіх сільськогосподарських угідь (рис. 1).

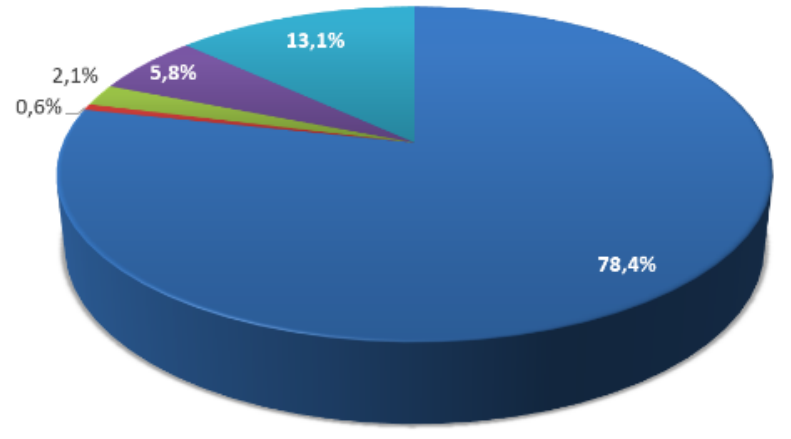

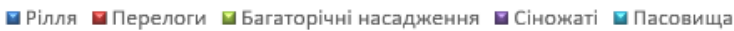

Рис. 1. Структура сільськогосподарських угідь

Площа чорноземів в Україні становить близько 17,4 млн. га, або 8\% від їх світових запасів. Усі сільськогосподарські угіддя за фрормою власності поділяються на: приватні - 74,8\%, державні - 25,1\% і комунальні - 0,1\%. Рілля за формою власності розподілена таким чином: 84,3\% - приватна; 15,6\% державна; 0,1\% - комунальна. Розподіл сільгоспугідь за фрормою власності наведено на рис. 2.

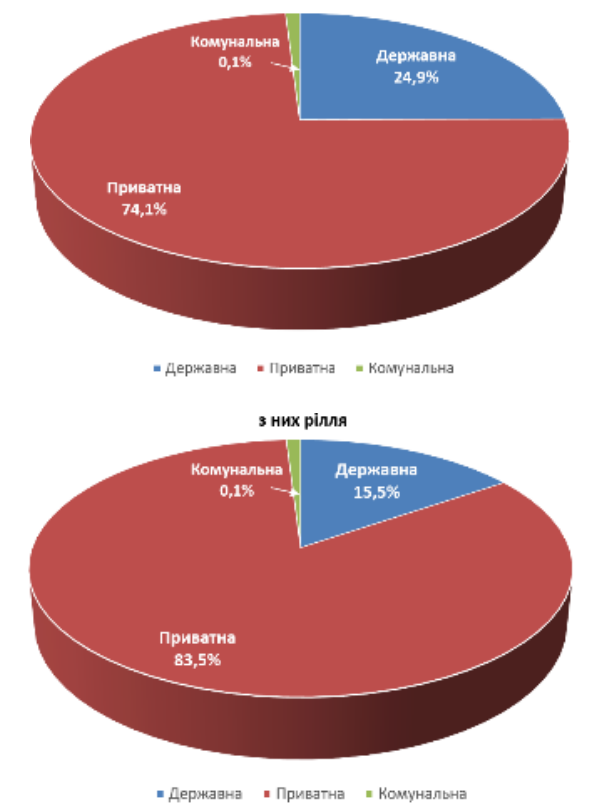

Рис. 2. Розподіл сільськогосподарських угідь за формою власності

Такий розподіл став наслідком приватизації колективних сільгосппідприємств та подрібнення 
сільгоспугідь у 90-х роках 20 століття. В Україні з'явилось 6,9 млн. власників земельних паїв (середній розмір паю - 4 га), дві третини з яких (4,9 млн.) здають ріллю площею 16,6 млн. га (51\%) в оренду. Усього ж в приватну власність було передано 27 млн. га сільськогосподарських земель. Зараз 4,8 млн. га розпайованих земель, або близько $12 \%$ усіх сільгоспугідь не використовуються.

Тобто, із-за хибності чинного земельного законодавства близько 1,2 млн. осіб не обробляють і не здають земельні ділянки в оренду [1]. Відсутність матеріальних ресурсів і коштів у власників земельних паїв змушує їх здавати свої ділянки в оренду на кабальних умовах за мізерну плату. Так, в середньому по Україні власники паїв торік отримали 1369 грн. орендної плати за гектар. Державні ж землі за минулий рік здавалися в оренду вдвічі дорожче, ніж приватні паї. Середній розмір плати за оренду сільгоспземель в Україні суттєво нижчий (41 євро/га), ніж в країнах Євросоюзу - навіть колишніх побратимах по Радянському Союзу (в Латвії - 46 євро/га, Естонії 52 євро/га, Литві - 81 євро/га) [2,3]. Середній розмір плати за оренду сільськогосподарських земель по регіонах України в 2017 році та країнах Євросоюзу показано на рис. 3 і 4.

Отже, 64\% сільгоспземель перебуває в оренді терміном від 7 до 50 років. Оренда в Україні домінує та підтримується законодавчою й виконавчою гілками влади. Але чи є це виправданим в економічному, соціальному та екологічному сенсі?
Дешева оренда приватних паїв зубожілих селян та державних земель, які держава не бажає сама ефективно використовувати, вже призвела до серйозної екстенсифрікації сільгоспвиробництва на користь орендарів та збанкрутіння держави. Сьогодні до господарського використання залучено понад 92\% території України. Рівень розораності території досяг понад 54\% (у розвинених країнах Європи - не перевищує 35\%) та порушив екологічно збалансоване співвідношення сільгоспугідь, лісів і водойм, що негативно вплинуло на екосфреру. Лісистість території в Україні складає $16 \%$, тоді як в Європі - 30\%. Зараз в країні вже нараховується більше 1,1 млн. га деградованих, малопродуктивних та техногенно забруднених земель, що підлягають консервації, 143,4 тис. га порушених земель, які потребують рекультивації та 315,6 тис. га малопродуктивних угідь, що потребують поліпшення. Біля 13,3 млн. га і в тому числі 10,6 млн. га ріллі зазнали нищівного впливу водної ерозії, з яких 68 тис. га повністю втратили гумусовий шар. Вітровій ерозії піддається понад 6 млн. га, а пиловим бурям - до 20 млн. га. За останні 20 років вміст гумусу зменшився на 0,22\%, а для його збільшення на 0,1\% в природних умовах необхідно 25-30 років. Щороку ґрунт втрачає по 400-500 кг органіки з гектара, відновлювати ж ці втрати нічим (тваринництво практично занедбане). Сьогодні органічних добрив вноситься в 14 разів менше, ніж за радянських часів.

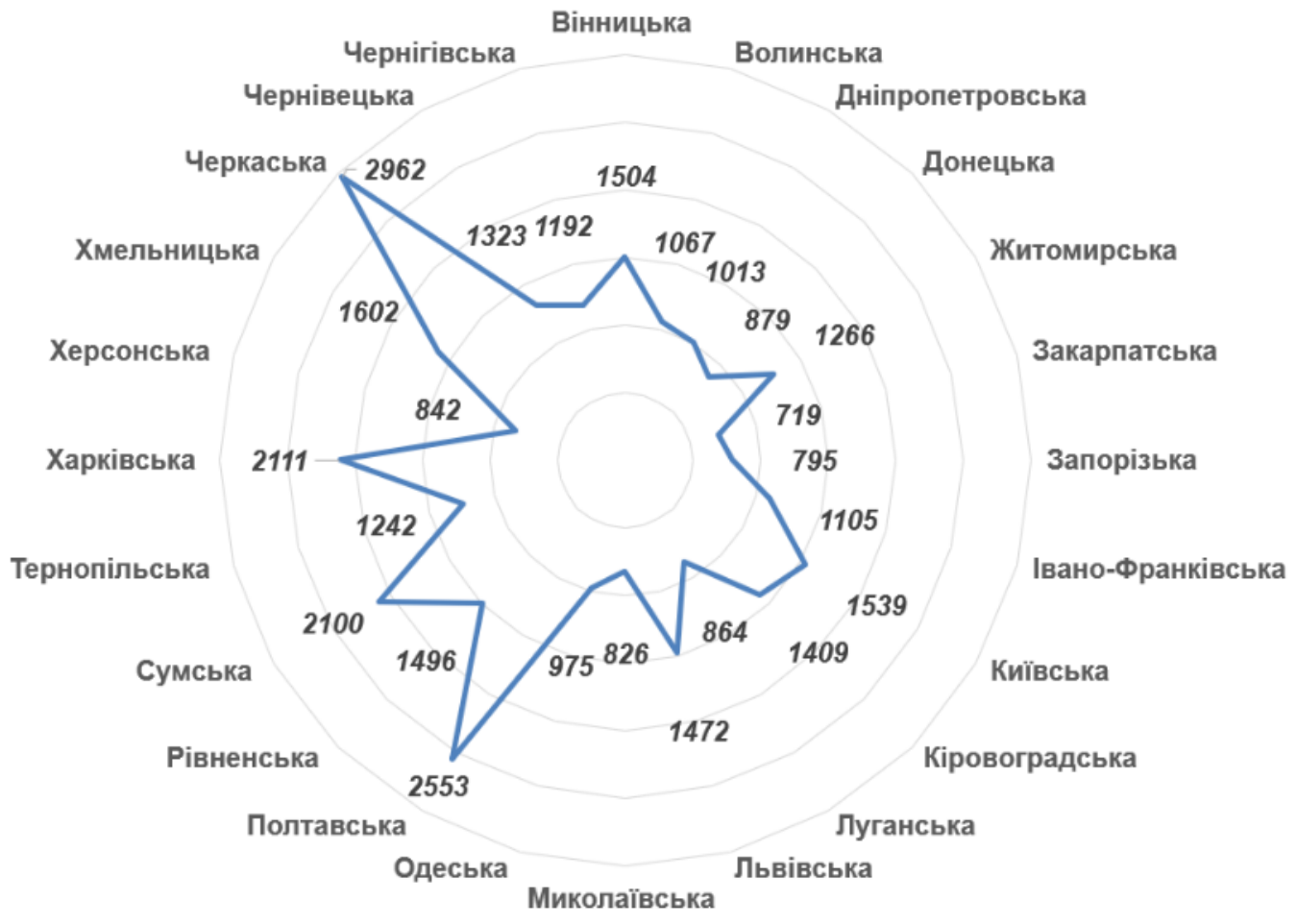

Рис. 3. Середній розмір плати за оренду сільськогосподарських земель по регіонах України у 2017 році, грн/га (Джерело: Держгеокадастр)

Інженерія природокористування, 2020, №4(18), с. 100 - 113

Engineering of nature management, 2020, \#4(18), p. 100 - 113 


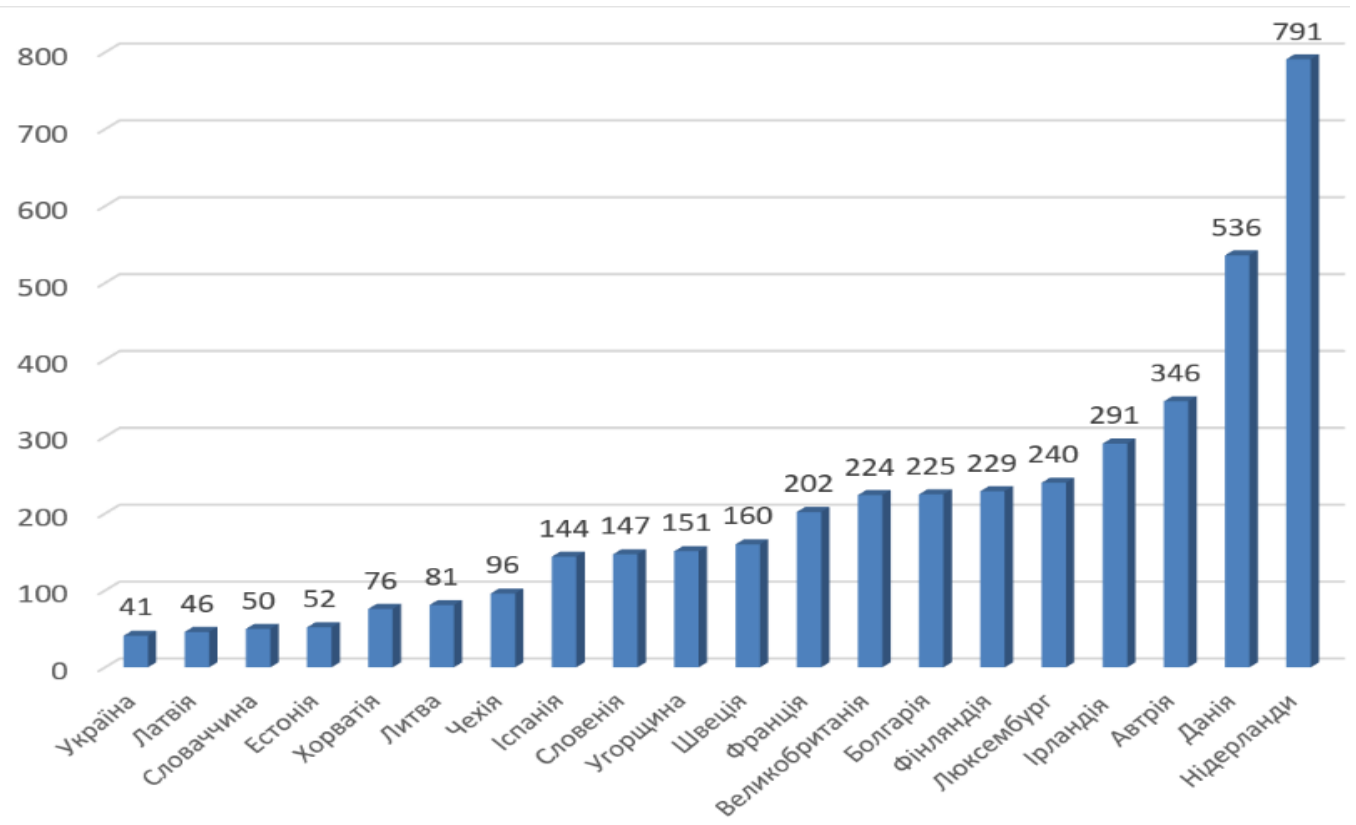

Рис. 4. Середній розмір плати за оренду землі сільськогосподарського призначення в окремих країнах Євросоюзу та Україні, евро/га (Джерело: Євростат, Держгеокадастр)

Отже, щоб підтримувати належний стан ґрунтів, у ріллю треба вносити достатню кількість добрив (органічних і мінеральних), дотримуватися сівозмін, вживати ґрунтозахисних заходів та мати в країні неупереджений, незалежний і некорумпований державний нагляд за землекористуванням. Звісно, це витрати на придбання добрив, довгострокові інвестиції в розвиток тваринництва, тимчасова відмова від прибутків на час відпочинку землі та виведення системи нагляду 3під місцевого підпорядкування виключно на рівень держави.Але сьогодні орендарі щорічно вносять тільки по 48 кг добрив на гектар, що у 2,5 рази менше ніж в ЄС. Згідно з дослідженнями Групи стратегічних радників з підтримки реформ в Україні частка рослинництва в Україні становить понад 70\% від об'єму сільгоспвиробництва (в Німеччині - 52\%), а це означає, що тваринництво занедбане, органічні добрива взяти ніде й кожен 4-й га ріллі закислений, бо аграрії використовують не органічні добрива, а азотні. Вимоги ж щодо дотримання сівозмін та обов'язкового впровадження ґрунтозахисних заходів, орендарями взагалі ігноруються. Так, виснажливий для землі соняшник у більшості господарств орендаторів займає площу понад $30 \%$ орних земель та висівається на одних і тих же землях по 5-7 років підряд. Така ж сама ситуація склалась й по інших культурах (ріпак, соя, пшениця), що мають значний попит на зовнішніх аграрних ринках. Недотримання цих вимог призводить до виснаження ґрунтів, значних втрат гумусу і різкого зниження врожайності. Дійсно, середній урожай пшениці з гектара на українських чорноземах ледь сягає 3 тонн, а у Великобританії, Франції та Німеччині - в середньому понад 7 тонн. Тобто концентрація земель сільгосппризначення в орендарів вже призвела до значної втрати найбільш родючих земель, переданих в оренду. Тому сьогодні необхідно скасувати існуючу оренду землі, як фоорму господарювання [4]. Створити потужний державний сектор товарного сільгоспвиробництва (адже $25,1 \%$ сільгоспземель перебуває на балансі держави), заснувати на добровільних засадах комунальні сільськогосподарські об'єднання дрібних приватних землевласників, пайщиків та підтримати успішні індивідуальні господарства[1-4].

Аналіз останніх досліджень і публікацій. При дослідженні звітів Держстату України к.е.н. Дніпропетровського державного аграрно-економічного університету Гаркавий В.В. [5] встановив, що протягом останніх років суттєво зростають площі сільгоспугідь, які відводяться під зернові культури й соняшник без дотримання вимог щодо сівозмін та оптимізації структури посівів, а також без внесення необхідної кількості мінеральних та органічних добрив. При цьому урожайність зернових 31 га коливається в межах від 30 до 41 центнера, з тенденцією до зменшення в останні роки. Урожайність же соняшника, при збільшенні площ збирання на $10 \%$, утримується на одному рівні 20-21 центнери з гектара. У своїй статті О. Цилюрик [6] наголошує, що можливості подальшого розширення площ орних земель в Україні вичерпані й збільшити виробництво аграрної продукції можна тільки за рахунок більш ефективного використання ґрунтів. Головною ж у вирішенні проблем землеробства $€$ оптимізація структури посівних 
площ з урахуванням науково-обґрунтованих рекомендацій та сівозмін. Проте в останні 25 років (у зв'язку з різким скороченням тваринництва) посівні площі кормових культур скоротились з 35\% до 6\%, посівні ж площі соняшника збільшилися 3 $10 \%$ до $37 \%$, а в південних районах Степу - до 50\%. При цьому дуже погіршуються кількісні та якісні характеристики ґрунтів, їх фрітосанітарний стан, вологозабезпеченість посівів наступних культур, що обумовлює зниження їх урожайності. Під час вирощування у сівозміні, навіть без добрив, урожайність пшениці озимої більша на 80\%, ніж на неудобрених беззмінних посівах. Автори Єщенко В.О. [7] та Бойко П. [8] у своїх наукових статтях стверджують, що збільшення виробництва рослинницької продукції сьогодні можливе тільки при впровадженні науково обґрунтованої системи землеробства, основною ланкою якої $€$ сівозміна. Саме на основі правильної сівозміни можна успішно запровадити всі інші елементи сучасних технологій: обробку ґрунту, захист рослин від шкідливих організмів, удобрення тощо. Серед головних причин ігнорування сівозмін вони зазначають перехід від планового рослинництва до ринкового, гонитву орендарів за надприбутками, занепад тваринництва та відсутність в Україні чіткого й дієвого державного нагляду за землекористуванням і своєчасним впровадженням ґрунтозахисних і природоохоронних заходів.

Мета статті. Проаналізувати законодавчоправові причини неефективності та бездієвості державного управління, нагляду і контролю за впровадженням орендарями України ґрунтозахисних і природоохоронних заходів. Надати пропозиції та рекомендації з удосконалення державного нагляду за впровадженням в землеробство і рослинництво заходів охорони та раціонального використання земель.

\section{Виклад основного матеріалу}

За 28 років незалежності повністю зруйнована радянська система державного землекористування та нагляду за дотриманням законодавства в цій галузі. Створена нова система, в якій значна площа ріллі належить дрібним власникампайщикам, що не мають засобів і коштів для ії обробітку і збору урожаю. Натомість колгоспна техніка, знаряддя праці опинились у руках орендарів (у минулому голів колгоспів і радгоспів, секретарів первинних організацій КПРС, агрономів, керівників місцевих органів влади). Саме вони стали диктувати умови оренди землі, визначати розмір орендної плати, розподіляти на свій розсуд отриманий з земельних паїв дрібних землевласників прибуток, вмотивовувати діяльність органів державної влади, формувати депутатський корпус сільських, районних, обласних рад, нехтувати природоохоронними вимогами чинного законодавства. Станом на кінець 2017 року в Україні чинні 50553 договори оренди 1,4 млн. га сільськогосподарських земель державної власності, які укладені на безконкурентних засадах. Водночас на монопольних засадах було укладено 4,7 млн. договорів оренди приватних земельних паїв загальною площею близько 17 млн. га [9]. Цьому ж суттєво сприяло упереджено складене та наспіх прийняте земельне законодавство. Так, частиною 3 статті 78 Земельного кодексу України встановлено три форми власності на землю - приватна, комунальна, державна. Статтею 13 Конституції України саме до компетенції Верховної ради і Кабінету Міністрів України, а також відповідних органів на місцях віднесена вся розпорядча й виконавча ініціатива по створенню підприємств і визначенню їх форм власності. Проте ні в кодексі, ані в інших фахових законах не передбачено створення певного відсотка державних та комунальних підприємств з товарного сільськогосподарського виробництва (державного продовольчого резерву) у первинному секторі економіки кожного адміністративного району України. Адже зараз в державі Ізраїль досить успішно функціонують комунальні підприємства - кібуци і мошави. Нині в 270 кібуцах живе 3\% населення країни та виробляється 33\% агропродукції Ізраїлю. Поряд з ними існують 450 мошавів, у кожному з яких близько 60 сімей $(3,1 \%$ населення), що виробляють $43 \%$ свіжої сільськогосподарської продукції країни. Тобто, 76\% продукції виробляється в кібуцах і мошавах, при плановому веденні трудової діяльності в цих комунах. В короткий термін їх мешканці, тільки частина з яких проходила спеціальне навчання, створили потужне високоефективне сільське господарство, яке по продуктивності й якості не поступається країнам 3 розвиненим землеробством [10]. Частка сільського господарства у складі ВВП деяких країн світу наведена у таблиці 1 [11].

Тенденція упередженості українського земельного законодавства чітко відстежується і в частині 4 статті 84 Земельного кодексу. В ній до земель державної власності, які не можуть передаватись до приватних, попередньо не віднесені особливо цінні землі кожного району, в якості стратегічного ресурсу для гарантованого забезпечення продуктових потреб держави та потреб держрезерву країни. Тобто, державні й громадські інтереси в товарному сільгоспвиробництві законодавчо були вилучені на користь орендарів, яким попередньо були передані засоби виробництва, знаряддя праці, надана пільгова фінансова підтримка та монопольне становище в галузі землекористування. В підтвердження цього 10 жовтня 2019 року Верховною Радою України був прийнятий проект Закону України «Про внесення змін до деяких законодавчих актів України щодо обігу земель сільськогосподарського призначення» №2178-10 [12].
ISSN 2311-1828

http://enm.khntusg.com.ua
Інженерія природокористування, 2020, №4(18), с. 100 - 113

Engineering of nature management, 2020, \#4(18), p. 100 - 113 
Таблиця 1. Частка сільського господарства у ВВП деяких країн світу

\begin{tabular}{|l|c|c|}
\hline Країна & $\begin{array}{c}\text { Частка } \\
\text { сільського } \\
\text { господарс- } \\
\text { тва в } \\
\text { ВВП, \% }\end{array}$ & $\begin{array}{c}\text { Річний обсяг } \\
\text { сільськогос- } \\
\text { подарського } \\
\text { виробниц- } \\
\text { тва, } \\
\text { US \$ млн. }\end{array}$ \\
\hline Світ загалом & 5,7 & 4245360 \\
\hline США & 1,2 & 176640 \\
\hline Євросоюз & 1,8 & 268380 \\
\hline Росія & 4,2 & 93618 \\
\hline Китай & 9,6 & 947712 \\
\hline Індія & 16,1 & 651406 \\
\hline Пакистан & 21,8 & 98362 \\
\hline Україна & 13,0 & 17268 \\
\hline Польща & 4,0 & 29008 \\
\hline Турція & 8,8 & 84330 \\
\hline Великобританія & 0,9 & 19701 \\
\hline Німеччина & 0,8 & 23680 \\
\hline Франція & 1,8 & 38880 \\
\hline Італія & 1,8 & 32076 \\
\hline Канада & 2,0 & 26700 \\
\hline Ізраїль & 2,0 & 4672 \\
\hline Японія & 1,1 & 47718 \\
\hline
\end{tabular}

За цей проект закону в першому читанні вже проголосувала більшість - 240 депутатів. У ньому передбачається вільний продаж земель в Україні. Орендарям, які злочинними методами землеробства і рослинництва вже знищили більшу частину найцінніших приватно-пайових чорноземів України, цим проектом закону надається переважне право купівлі орендованих земель??! Інакше кажучи, злочинцям винесли подяку за знищення основного національного багатства України, яке буцім-то перебуває під особливою охороною держави. Окрім того встановлено, що землі державної й комунальної власності будуть реалізовуватись виключно на торгах. Жодного слова в проекті закону про створення в країні потужного державного і комунального секторів сільськогосподарського виробництва, як те й передбачено чинним Земельним кодексом України, немає! Водночас жодних пільг чи преференцій дрібним власникам паїв в питаннях передачі своїх ділянок в оренду чи їх продажу проектом закону не передбачається. Зокрема проведення державних аукціонів з передачі приватно-пайових земель в оренду або з їх продажу не заплановано. Монопольний пріоритет оренди і купівлі приватного паю цим проектом закону, чинним земельним законодавством, а також органами місцевої влади і місцевого самоврядування чітко закріплюється за територіально призначеними місцевими орендарями. В разі ж виникнення у власника приватного паю бажання організувати аукціон $з$ передачі землі в оренду або з її продажу, йому потрібно буде фрінансувати аукціон 3 власної кишені! А при зарплатах 50\% працівників України від 4173 грн і до 6000 грн [13] та середньому по країні розмірі пенсій - 2646 грн [14] це бажання буде довічно нездійсненним!!! Це свідчить про те, що встановлене статтями 5 і $13 \mathrm{Koн-}$ ституції України делегування Українським народом функцій здійснення влади і прав власникарозпорядника землі органам державної влади та місцевого самоврядування цілком ігнорується ними, а народ не визнається єдиним носієм суверенітету і влади в Україні!

Однобокий підхід органів державної законодавчої влади висвітлився і при прийнятті Закону України «Про оцінку земель» у 2004 році. Так, статтею 3 цього закону до об'єктів оцінки земель віднесені території адміністративно-територіальних одиниць, оціночних районів, окремих земельних ділянок. Проте не визначені конкретні державні установи, відповідальні за проведення оціночних робіт у цілому в державі, вказаних одиницях і районах. Статтею 4 задекларовані принципи проведення оцінки земель, серед яких безперервність процесу оцінки, доступність використання даних з оцінки земель, рівність перед законом усіх суб'єктів оціночної діяльності. При цьому який механізм контролю за дотриманням цих принципів, які правоохоронні органи і в якій послідовності його забезпечуватимуть - в законі не наведено. Це вже призвело до порушення безперервності оцінки. Передостання оцінка земель на державному рівні проводилась у 1993-1995 роках, тобто 25 років тому, замість регламентованої оцінки раз у 7 років. Весь цей час Держгеокадастр України, Міністерство аграрної політики та продовольства, Кабінет Міністрів України використовували упереджено застарілі, занижені хибні дані. При цьому навіть ці дані не були доступні для широкого загалу, а були власністю установ Держгеокадастру, які продавали їх як свою, а не народну власність. Все це завідомо скасувало принцип рівності перед законом усіх суб'єктів оціночної діяльності та поставило народ України в цілковиту залежність від функціонерів державної влади, які утримуються з народних же податків. Статтею 13 цього закону встановлюється обов'язковість проведення нормативної грошової оцінки земельних ділянок (НГОЗД) у разі визначення розміру земельного податку, визначення втрат сільськогосподарського виробництва і розробки показників та механізмів економічного стимулювання раціонального використання й охорони земель. Проте протягом минулих 25 років по більшості приватних паїв України НГОЗД взагалі не проводилась, а Державна фріскальна служба та Держгеокадастр України весь цей час визначали розмір земельного податку по занижених і 
застарілих даних. Тобто упереджено зменшували розміри орендної плати та надходжень до бюджетів. При цьому жодні наглядові дії з виправлення такого ганебного становища не вживались, чим грубо порушувались вимоги чинного податкового й земельного законодавства та відповідних положень про ці органи. Разом з тим, оскільки протягом останніх 25 років НГОЗ не проводилась стає зрозумілим, що ні Міністерство аграрної політики та продовольства, ні Міністерство екології та природних ресурсів України, а ні місцеві органи державної влади та місцевого самоврядування весь цей час жодним чином не відстежували втрати сільськогосподарського виробництва, не розробляли та не впроваджували показники й механізми економічного стимулювання раціонального використання й охорони земель нашої країни. Тобто спеціально на те уповноважені державні органи не цікавили питання ефективного використання головного національного багатства України. І хоча згідно з постановою Кабінету Міністрів України від 7.02.2018р. №105 Міністерство аграрної політики та продовольства України разом з Держгеокадастром провели в 2018 році загальнонаціональну (всеукраїнську) нормативну грошову оцінку земель сільськогосподарського призначення на всій території України, але ії хибність, фріктивність й упередженість вже були закладені на рівні самої постанови! Так, пунктом 6 Порядку проведення загальнонаціональної (всеукраїнської) нормативної грошової оцінки земель сільськогосподарського призначення, затвердженого зазначеною постановою, приписується цим органам державної влади використовувати в якості вихідних даних для проведення оцінки застарілі грунтові обстеження минулих років?! Водночас пунктом 7 передбачається проводити грунтові обстеження тільки у разі потреби?! Ця вимога в різних інтерпретаціях повторюється також у пунктах 9, 10, 12. Підтвердженням цілковитого небажання центральних органів виконавчої влади виконувати зазначену роботу на належному законодавчому рівні $€$ і вимога пункту 24 Порядку щодо продовження чинності технічних документацій з НГОЗД, які попередньо були затверджені рішеннями органів місцевого самоврядування до 2018 року. Цим же пунктом приватним власникам земельних ділянок сільськогосподарського призначення (паїв) наказується після закінчення терміну дії застарілої НГОЗД (виконаної ними за власний кошт) виконувати цю роботу й надалі за свій кошт. Тобто держава, яка за податки своїх громадян вже провела оцінку земель не бажає ділитися з ними цією інформацією, а наполягає на додатковому здирництві за вже сплачені послуги??! Саме це свідчить, що Кабінет Міністрів України, Мінагрополітики, Держгеокадастр, Мінприроди навіть не планували цією постано- вою з'ясовувати фрактичну вартість сільськогосподарських земель України, зміни якісних і кількісних характеристик грунтів країни, спричинені хижацьким землекористуванням орендарів протягом минулих 25 років. Стає зрозумілим, що ніхто не планує виявляти фактичних винуватців збитків, заподіяних недбалим землекористуванням, для їх подальшого стягнення 3 порушників чинного законодавства. Адже для цього, згідно з вимогами статті 36 Закону України «Про землеустрій» конче необхідно було б провести одночасні детальні грунтові, агрохімічні, геоботанічні та інші обстеження всіх сільськогосподарських земель країни. Саме ці обстеження дали б інформацію про якісний стан земель. Допомогли б виявити еродовані, техногенно забруднені сільськогосподарські землі та привести їх до екологічної норми. Створили б вірогідну основу для проведення правильного бонітування, врахування економічних факторів урожайності основних культур та угідь господарств орендарів, під час економічної оцінки земель. Стали б правдивою підставою для проведення нормативних грошових оцінок окремих земельних ділянок [15]. Відсутність же надійних вказаних даних призвело до неможливості правильного визначення капіталізованого рентного доходу, який отримують при вирощуванні сільсгоспкультур на кокретних земельних ділянках. Інакше кажучи правдива нормативна грошова оцінка земель України і цього разу не проведена. Мінагрополітики, Держгеокадастр та Мінприроди України вкотре відбули чергу й створили чисту фікцію. Себто нечіткість законодавства, посилена безконкретністю та розмитістю постанов уряду призвела до нівелювання положень Конституції України про землю, як основне національне багатство, що перебуває під особливою охороною держави (стаття 14).

Дуалізм тлумачення Закону України «Про оцінку земель» помітний і в статті 15, де в якості підстави для проведення оцінки земель пропонується приймати рішення органу виконавчої влади або органу місцевого самоврядування раз на 7 років. В той же час який саме з органів, у які терміни та в якому випадку повинен це робити, або перед ким саме нести відповідальність за неприйняття рішення не зазначено?!

Статтею 5 цього ж закону визначені види оцінки земель: бонітування грунтів; економічна оцінка земель та грошова оцінка земельних ділянок. При цьому встановлено, що дані бонітування ґрунтів - це основа для проведення економічної оцінки земель, визначення екологічної придатності ґрунтів для певних сільгоспкультур та втрат виробництва. Статтею 16 встановлено, що бонітування на землях сільгосппризначення повинні проводити юридичні особи-розробники документації із землеустрою не рідше одного разу у
ISSN 2311-1828

http://enm.khntusg.com.ua
Інженерія природокористування, 2020, №4(18), с. 100 - 113

Engineering of nature management, 2020, \#4(18), p. 100 - 113 
7 років. Проте протягом 25 років воно взагалі не проводилось, а в 2018 році воно проведено швидко, проте фріктивно! Водночас економічна оцінка земель востаннє виконана в 1988 році за результатами господарювання колгоспів і радгоспів у 1981-1987 році. При цьому ця ж робота в 2018 році проведена взагалі без аналізу економічної діяльності господарств орендарів? Зрозуміло, що дані таких оцінок цілком хибні й повністю не відповідають сьогоднішнім умовам діяльності орендарів і отримуваним ними прибуткам. Тобто протягом 25 років Кабінет Міністрів України та його органи на місцях 4 рази порушували вимоги чинного земельного, податкового, бюджетного й природоохоронного законодавства! За 25 років ні Мінагрополітики, ні Держгеокадастр, ні Мінприроди України жодного разу не проводили всеукраїнські дослідження основних природних властивостей грунтів (морфологічних, генетичних, хімічних і фрізичних). Нормативна ж грошова оцінка земель України, ініційована та проведена в 2018 році урядом Порошенка-Гройсмана, також виконана емпірично без суміщених в часі першочергових детальних грунтових та економічних досліджень орендаторських господарств (постанова КМУ від 7.02.2018p. №105). До речі в Німеччині бонітування проводиться систематично по 9 видах механічного складу, 5 групах геологічного походження, 7 ступенях природного стану грунтів, 3 врахуванням продуктивності земель (зумовленої якістю грунту, рельєфом, кліматом) і економічних умов дохідності (ринків збуту, шляхів постачання тощо). Відсутність систематичних досліджень грунтів в Україні на потужність гумусового горизонту, відсотковий вміст в них гумусу, мулу і фрізичної глини, валовий запас гумусу, азоту, фоссрору і калію, максимально можливі запаси продуктивної вологи, механічний склад, кислотність, суму поглинутих основ тощо, свідчить про суттєву недбалість органів державної влади, місцевого самоврядування, держнагляду й правоохоронних органів у підтриманні високих показників урожайності грунтів та збереженні головного національного багатства України. Неврахування продуктивності земель, екологічної збалансованості їх використання та дохідності з одиниці площі вже призвело до застосування протягом 25 років хибних застарілих землеоціночних даних та злочинних методів сільгоспвиробництва орендарями. Те ж саме тепер продовжено на перспективу фіктивно проведеною в 2018 році Держгеокадастром України нормативною грошовою оцінкою земель. Внаслідок цього були і тепер залишаться на тривалий час суттєво занижені розміри вартості земель України, надходжень земельних податків до бюджету, виплат орендної плати, чим грубо порушені вимоги статей 271, 274, 284, 286, 288 Податкового кодексу України. Таким чином державна влада в
Україні цілком зневажає законні інтереси єдиного носія влади та суверенітету - народу України (стаття 5 Конституції України). Незважаючи на 25ти річну застарілість землеоціночних даних, Кабінет Міністрів України в 2018 році постановою від 7.02.2018p. №105 підтримав ініціативу Мінагрополітики й Держгеокадастру України про «продовження» використання хибних державних даних 3 оцінки земель. Це в свою чергу дозволить органам Держгеокадастру Мінекономрозвитку України, Держекоінспекції Мінекоенерго України та Державної фріскальної служби Мінфіну України й надалі бездіяти та не вживати жодних заходів держнагляду до органів місцевої влади, місцевого самоврядування та орендарів-землекористувачів приватних паїв, по безумовному виконанню ними вимог Земельного, Податкового кодексів України та природоохоронного законодавства.

Окрім того це дозволяє органам Держгеокадастру Мінекономрозвитку України в повсякденній діяльності постійно застосовувати подвійні монопольні підходи до державної реєстрації права оренди земельних ділянок (стаття 17 Закону України «Про оренду землі») [16]. Так, коли орендарі земельних паїв, користуючись правовою необізнаністю їх власників і заступництвом органів місцевої влади та самоврядування, самі формують договори оренди, то зазвичай закладають суттєво застарілі, упереджено занижені показники нормативної грошової оцінки земельних ділянок (НГОЗД). Тоді здебільшого в договори закладається мінімальний відсоток НГОЗД (3-4\% замість 10-12\% згідно зі статтею 288.5.2 Податкового кодексу України) орендної плати, а відтак автоматично зменшується і розмір земельного податку та розмір надходжень до бюджету. При цьому державна реєстрація таких договорів відбувається швидко, без жодних зауважень і зволікань, як з боку місцевих управлінь Держгеокадастру, так і з боку місцевих управлінь Державної фріскальної служби (ДФС) Мінфіну України. Коли ж власники паїв самі бажають провести реєстрацію власноруч підготовлених і законодавчо вмотивованих договорів оренди, то тут окрім перепон з боку орендарів обов'язковими стають переробка технічної документації з НГОЗД (при відсутніх достовірних державних даних бонітування, економічної та грошової оцінки грунтів), довготривала її експертиза, небажання органів влади і місцевого самоврядування погоджувати документацію та небажання орендарів долучати її до договору? Себто в повсякденній діяльності місцевих органів Держгеокадастру Мінекономрозвитку, ДФС Мінфіну та Держекоінспекції Мінекоенерго України, органів державної влади та місцевого самоврядування постійно присутні ознаки упередженої прихильності до орендарів приватно-пайових земель, зловживань монопольним становищем на ринку оренди землі та корупційних діянь. 
Байдужість держави до питань особливої охорони основного національного багатства (ст. 14 Конституції України) висвітлилась також в статті 24 Закону України «Про оцінку земель». Так, цією статтею встановлюється можливість проведення фрінансування робіт з оцінки земель за рахунок коштів Державного бюджету України, місцевих бюджетів, коштів землевласників, землекористувачів й інших джерел, не заборонених законом, при цьому жодним чином не конкретизується - які ж види оціночних робіт за рахунок коштів яких бюджетів і у яких випадках повинні проводитись?!

Чинне земельне законодавство надає суттєві правові переваги в діяльності саме орендарям землі. Так, частиною третьою статті 6 Закону України «Про оренду землі» орендодавці (дрібні власники приватних паїв) зобов'язуються відшкодовувати збитки орендарям у випадку дострокового припинення ними договорів оренди? Статтею 7 цього ж закону за орендарями землі зберігається пріоритет переходу права на оренду землі до спадкоємців чи співкористувачів після смерті чи засудження основного орендаря? Статтями 8, 81 та 82 орендарям дозволяється передавати орендовані земельні ділянки в суборенду, обмінюватись між собою правами землекористування, відчужувати право оренди земельної ділянки, ба навіть без згоди на те орендодавця (достатньо по пошті надіслати орендодавцеві повідомлення)??! Переважне право на отримання орендованої земельної ділянки у власність закріплюється також за орендарями статтею 9 зазначеного закону. Окрім того, статтею 11 закону ризик випадкового знищення або пошкодження об'єкта оренди (в тому числі й приватно-пайової земельної ділянки) покладено не на безпосереднього землекористувача-орендаря, який дійсно може пошкодити землю недбалим землекористуванням, а на орендодавця, який не має ні засобів, а ні знарядь праці для її обробітку та є скоріш за все, при чинній судовій і правоохоронній системах України, простим статистом злочинів орендаря! Це при тому, що орендар згідно зі статтею 25 має право самостійно вибирати методи землекористування (хижацькі чи екологоощадні), а орендодавцеві статтею 24 заборонено перешкоджати йому «користуватися орендованою земельною ділянкою». Більш того, від орендодавця вимагається відшкодовувати орендарю капітальні витрати, пов'язані з поліпшенням стану об'єкта оренди. Тобто, всі прибутки залишаються орендареві, а от орендодавцеві (приватному пайщикові) буде виплачено 3-6\%, але не від прибутку чи обсягу врожаю, а від безнадійно заниженого та занадто фіктивного показника НГОЗД. При цьому орендар не несе ніякої відповідальності за збереження родючості земель, що перебувають в його оренді. Орендодавець же повинен сплачувати не тільки збитки й втрати орендаря, але й вкладати свої особисті кошти заробітної плати (пенсії) у відновлення родючості знищених орендарем грунтів і забезпечувати орендареві постійні високі врожаї!? Отже чинне земельне законодавство України визнає саме орендаря справжнім власником усіх земель, які перебувають в його користуванні!!! Це остаточно закріплюється статтею 27 Закону України «Про оренду землі», де орендарям забезпечується захист їх права на орендовані земельні ділянки на рівні з захистом права власності на цю ділянку. Окрім того, статтею 28 цього закону орендарям надане право на відшкодування збитків за рахунок орендодавця. Таким чином на рівні адміністративних районів України впроваджено цілковитий монополізм орендарів, які за підтримки районних державних адміністрацій, районних рад, управлінь Держгеокадастру, об'єднаних державних податкових інспекцій ДФС, державних екологічних інспекцій мають необмежені права довільного землекористування та одночасного пограбування як орендодавців-пайщиків, так і в цілому держави!

Правова нерівність орендодавців приватних земель-паїв та орендодавців державних і комунальних земель добре помітна в чинній процедурі набуття і реалізації права оренди землі. Так, частиною 2 статті 124 та частиною 1 статті 134 Земельного кодексу України передбачається обов'язковість передачі земель державної або комунальної власності в оренду на конкурентних засадах (за результатами земельних торгів). Частинами 1 та 2 статті 135 Земельного кодексу України, частиною 2 статті 16 Закону України «Про оренду землі» по землях державної та комунальної власності завбачається продаж права оренди виключно на земельних торгах (аукціонах), за результатами яких укладається договір оренди 3 переможцем, що запропонував найвищу ціну за користування ділянкою. Водночас частиною 1 статті 16 Закону України «Про оренду землі» встановлюється порядок укладання договору оренди земельних ділянок приватної власності тільки за згодою орендодавця та орендаря?! Себто власник приватного паю-орендодавець повинен умовити орендаря взяти в оренду свою земельну ділянку на вигідних для орендаря умовах! Якщо ж орендодавець-пайщик буде наполягати на гідних-рівноправних умовах оренди, то орендар вправі відмовитись від оренди, а жоден з інших орендарів району не буде заважати «побратиму по корпорації» демпінгувати й таким чином підтримувати загальні пільгові умови оренди землі на певній адміністративній території! Навіть якщо орендодавець-пайщик спробує продати право на оренду своєї приватної ділянки, то й тут його очікуватимуть не тільки корпоративність інтересів орендарів, а й цілковита байдужість до
ISSN 2311-1828

http://enm.khntusg.com.ua
Інженерія природокористування, 2020, №4(18), с. 100 - 113

Engineering of nature management, 2020, \#4(18), p. 100 - 113 
його проблем органів місцевої влади, місцевого самоврядування та спеціально уповноважених на це органів державного нагляду та контролю. Адже згідно з вимогами частин 2, 3, 5 статті 135 Земельного кодексу України земельні торги в цьому випадку будуть організовуватись виключно з ініціативи власника землі та при наявності у нього необхідних коштів на улаштування цього заходу! Оскільки орендодавець-пайщик фактично отримує від орендаря 3-6\% заниженої орендної плати (в середньому 300-600 грн на місяць), організація земельних торгів для нього - це нездійсненна мрія, яка упереджено піднята саме чинним законодавством на нездоланний рівень! При зверненні ж до органів місцевої влади та місцевого самоврядування з приводу надання допомоги в урегулюванні відносин з чинним орендарем чи знаходження альтернативних зацікавлених орендарів, орендодавець-пайщик завжди отримає законодавчо вмотивовану відповідь про неприпустимість втручання органів влади у відносини орендодавця і орендаря! Й це незважаючи на те, що статтею 13 Конституції України здійснення прав власника землі від імені Українського народу покладено на органи державної влади та органи місцевого самоврядування і саме держава уповноважена забезпечувати захист прав усіх суб'єктів права власності і господарювання, соціальну спрямованість економіки та рівність усіх суб'єктів права власності перед законом!

Сьогодні відомо, що збільшення виробництва рослинницької продукції можливе тільки при впровадженні науково обгрунтованої системи землеробства, основною ланкою якої $€$ сівозміна. Сівозміна - це науково обгрунтоване чергування сільськогосподарських культур і парів у часі і на території або тільки у часі. Саме сівозміна дозволяє впровадити агрономічну стратегію підвищення продуктивності грунту і врожайності сільськогосподарських культур, визначити та взаємопов'язати в єдиний комплекс усі ланки системи землеробства. Від спеціалізації сівозмін, складу і чергування культур залежать системи удобрення, механічного обробітку грунту та інших агротехнічних і меліоративних заходів. Орієнтовні схеми польових сівозмін для певних зон України наведені в таблицях 2, 3, 4. Проте незважаючи на наукову доведеність високої врожайності грунтів й збереження їх родючості внаслідок системного застосування сівозмін, чинне земельне законодавство України не обтяжує ні орендарів, ні державний нагляд, ані органи державної влади та місцевого самоврядування питаннями їх безумовного впровадження та дотримання під час оренди 16,6 млн. га (51\%) ріллі, яка належить зубожілим і безправним власникам паїв!!!
Таблиця 2. Орієнтовні схеми польових сівозмін для лісостепової зони

\begin{tabular}{|c|c|c|c|c|}
\hline \multirow[b]{2}{*}{$\begin{array}{l}\text { № } \\
\text { 3/ח }\end{array}$} & \multicolumn{4}{|c|}{ Виробничий тип сівозмін тип сівозміни } \\
\hline & $\begin{array}{l}\text { Зерново- } \\
\text { бурякова }\end{array}$ & $\begin{array}{l}\text { Зерново- } \\
\text { фруражна }\end{array}$ & \begin{tabular}{|c|} 
Польова- \\
кормова
\end{tabular} & $\begin{array}{c}\text { Польова- } \\
\text { кормова }\end{array}$ \\
\hline 1 & $\begin{array}{c}\text { Багаторі- } \\
\text { чні трави } \\
\text { на один } \\
\text { укіс }\end{array}$ & $\begin{array}{c}\text { Багаторічні } \\
\text { трави }\end{array}$ & $\begin{array}{c}\text { Багаторічні } \\
\text { трави }\end{array}$ & $\begin{array}{c}\text { Чистий і } \\
\text { зайнятий } \\
\text { пари }\end{array}$ \\
\hline 2 & $\begin{array}{c}\text { Озима } \\
\text { пшениця }\end{array}$ & $\begin{array}{c}\text { Озима } \\
\text { пшениця }\end{array}$ & $\begin{array}{c}\text { Багаторічні } \\
\text { трави } \\
\end{array}$ & $\begin{array}{c}\text { Озима } \\
\text { пшениця }\end{array}$ \\
\hline 3 & $\begin{array}{l}\text { Цукрові } \\
\text { буряки }\end{array}$ & $\begin{array}{c}\text { Цукрові бу- } \\
\text { ряки }\end{array}$ & $\begin{array}{l}\text { Озима пше- } \\
\text { ниця + пож- } \\
\text { нивні посіви }\end{array}$ & $\begin{array}{l}\text { Цукрові } \\
\text { буряки }\end{array}$ \\
\hline 4 & $\begin{array}{c}\text { Кукурудза } \\
\text { на зерно }\end{array}$ & $\begin{array}{l}\text { Кукурудза } \\
\text { на зерно }\end{array}$ & $\begin{array}{c}\text { Цукрові бу- } \\
\text { ряки, карто- } \\
\text { пля } \\
\end{array}$ & $\begin{array}{l}\text { Ячмінь } 3 \\
\text { підсівом } \\
\text { люцерни } \\
\end{array}$ \\
\hline 5 & Горох & $\begin{array}{l}\text { Горох } \\
\text { (чина) }\end{array}$ & Зернобобові & Люцерна \\
\hline 6 & $\begin{array}{c}\text { Озима } \\
\text { пшениця }\end{array}$ & $\begin{array}{c}\text { Озима } \\
\text { пшениця }\end{array}$ & $\begin{array}{c}\text { Озима пше- } \\
\text { ниця }\end{array}$ & $\begin{array}{c}\text { Озима } \\
\text { пшениця, } \\
\text { люцерна }\end{array}$ \\
\hline 7 & $\begin{array}{l}\text { Цукрові } \\
\text { буряки }\end{array}$ & $\begin{array}{l}\text { Цукрові бу- } \\
\text { ряки, куку- } \\
\text { рудза на } \\
\text { зерно }\end{array}$ & $\begin{array}{c}\text { Цукрові бу- } \\
\text { ряки }\end{array}$ & $\begin{array}{c}\text { Озимі } \\
\text { жито і } \\
\text { пшениця } \\
+ \text { пожни- } \\
\text { вні посіви } \\
\end{array}$ \\
\hline 8 & $\begin{array}{c}\text { Кукурудза } \\
\text { на силос } \\
\end{array}$ & $\begin{array}{c}\text { Однорічні } \\
\text { трави } \\
\end{array}$ & $\begin{array}{l}\text { Кукурудза на } \\
\text { зерно, гречка } \\
\end{array}$ & \begin{tabular}{|c|} 
Кукурудза \\
на зерно \\
\end{tabular} \\
\hline 9 & $\begin{array}{c}\text { Озимі + } \\
\text { пожнивні } \\
\text { посіви }\end{array}$ & $\begin{array}{c}\text { Озима } \\
\text { пшениця + } \\
\text { пожнивні } \\
\text { посіви }\end{array}$ & $\begin{array}{c}\text { Кукурудза на } \\
\text { зелений корм } \\
+ \text { поукосні } \\
\text { посіви }\end{array}$ & $\begin{array}{c}\text { Кукурудза } \\
\text { на силос, } \\
\text { зернобо- } \\
\text { бові }\end{array}$ \\
\hline 10 & $\begin{array}{c}\text { Ячмінь, } \\
\text { овес, } \\
\text { просо } 3 \\
\text { підсівом } \\
\text { багаторіч- } \\
\text { них трав }\end{array}$ & $\begin{array}{c}\text { Ячмінь } 3 \\
\text { підсівом } \\
\text { багаторіч- } \\
\text { них трав }\end{array}$ & $\begin{array}{l}\text { Ячмінь, овес, } \\
\text { просо з підсі- } \\
\text { вом люцерни }\end{array}$ & $\begin{array}{c}\text { Озимі } \\
\text { пшениця і } \\
\text { жито + по- } \\
\text { жнивні ку- } \\
\text { льтури }\end{array}$ \\
\hline
\end{tabular}

Таблиця 3. Орієнтовні схеми польових сівозмін для степової зони

\begin{tabular}{|c|c|c|c|c|}
\hline $\begin{array}{l}\text { № } \\
3 / \text { ח }\end{array}$ & \multicolumn{2}{|c|}{$\begin{array}{c}\text { Північні і центральні } \\
\text { райони Степу }\end{array}$} & \multicolumn{2}{|c|}{$\begin{array}{c}\text { Південні і південно-східні } \\
\text { райони Степу }\end{array}$} \\
\hline 1 & 2 & 3 & 4 & 5 \\
\hline 1 & $\begin{array}{l}\text { Пар чорний } \\
\text { і зайнятий }\end{array}$ & $\begin{array}{l}\text { Пар } \\
\text { чорний }\end{array}$ & $\begin{array}{l}\text { Пар } \\
\text { чорний }\end{array}$ & $\begin{array}{l}\text { Пар } \\
\text { чорний }\end{array}$ \\
\hline 2 & $\begin{array}{c}\text { Озима } \\
\text { пшениця }\end{array}$ & $\begin{array}{c}\text { Озима } \\
\text { пшениця }\end{array}$ & $\begin{array}{c}\text { Озима } \\
\text { пшениця } \\
\end{array}$ & $\begin{array}{l}\text { Озима } \\
\text { пшениця }\end{array}$ \\
\hline 3 & $\begin{array}{l}\text { Цукрові бу- } \\
\text { ряки }\end{array}$ & $\begin{array}{l}\text { Озима } \\
\text { пшениця }\end{array}$ & $\begin{array}{c}\text { Кукурудза з } \\
\text { розшире- } \\
\text { ними між- } \\
\text { ряддями } \\
\end{array}$ & $\begin{array}{l}\text { Кукурудза } \\
\text { на зерно }\end{array}$ \\
\hline 4 & $\begin{array}{l}\text { Кукурудза } \\
\text { на зерно }\end{array}$ & $\begin{array}{l}\text { Кукуру- } \\
\text { дза на } \\
\text { зерно }\end{array}$ & $\begin{array}{l}\text { Озима } \\
\text { пшениця }\end{array}$ & $\begin{array}{l}\text { Кукурудза і } \\
\text { сорго на зе- } \\
\text { рно і силос }\end{array}$ \\
\hline 5 & $\begin{array}{c}\text { Ярі зернові } \\
\text { з підсівом } \\
\text { еспарцету }\end{array}$ & Ячмінь & Соняшник & $\begin{array}{c}\text { Озима } \\
\text { пшениця, } \\
\text { озимий } \\
\text { ячмінь } \\
\end{array}$ \\
\hline
\end{tabular}


Продовження таблиці 3

\begin{tabular}{|c|c|c|c|c|}
\hline 1 & 2 & 3 & 4 & 5 \\
\hline 6 & Еспарцет & $\begin{array}{c}\text { Пар за- } \\
\text { йнятий }\end{array}$ & $\begin{array}{c}\text { Чорний і } \\
\text { зайнятий } \\
\text { пар }\end{array}$ & $\begin{array}{c}\text { Зайнятий } \\
\text { пар, баш- } \\
\text { танні }\end{array}$ \\
\hline 7 & $\begin{array}{c}\text { Озима } \\
\text { пшениця }\end{array}$ & $\begin{array}{c}\text { Озима } \\
\text { пшениця }\end{array}$ & $\begin{array}{c}\text { Озима } \\
\text { пшениця }\end{array}$ & $\begin{array}{c}\text { Озима } \\
\text { пшениця }\end{array}$ \\
\hline 8 & $\begin{array}{c}\text { Цукрові бу- } \\
\text { ряки, соня- } \\
\text { шник }\end{array}$ & $\begin{array}{c}\text { Кукуру- } \\
\text { дза на } \\
\text { силос, } \\
\text { зернобо- } \\
\text { бові }\end{array}$ & Ярі зернові & Ячмінь \\
\hline 9 & $\begin{array}{c}\text { Кукурудза } \\
\text { на силос }\end{array}$ & $\begin{array}{c}\text { Озима } \\
\text { пшениця }\end{array}$ & $\begin{array}{c}\text { Кукурудза, } \\
\text { сорго на } \\
\text { силос }\end{array}$ & Соняшник \\
\hline 10 & Озимі & $\begin{array}{c}\text { Соняш- } \\
\text { ник }\end{array}$ & $\begin{array}{c}\text { Озима } \\
\text { пшениця }\end{array}$ & Рицина \\
\hline
\end{tabular}

Таблиця 4. Орієнтовні схеми сівозмін в умовах зрошення степової зони

\begin{tabular}{|c|c|c|c|c|}
\hline $\begin{array}{l}\text { № } \\
\text { 3/ח }\end{array}$ & Польова & Кормова & Рисова & $\begin{array}{c}\text { Грунтозахи- } \\
\text { сна сівозміна } \\
\text { на схилах 3- } \\
7^{\circ}\end{array}$ \\
\hline 1 & Люцерна & Люцерна & Люцерна & $\begin{array}{c}\text { Багаторічні } \\
\text { трави }\end{array}$ \\
\hline 2 & Люцерна & Люцерна & Люцерна & $\begin{array}{c}\text { Багаторічні } \\
\text { трави }\end{array}$ \\
\hline 3 & $\begin{array}{c}\text { Озима } \\
\text { пшениця, } \\
\text { пожнивні } \\
\text { посіви }\end{array}$ & Люцерна & Рис & $\begin{array}{l}\text { Озима пше- } \\
\text { ниця з після- } \\
\text { жнивним по- } \\
\text { сівом на } \\
\text { корм }\end{array}$ \\
\hline 4 & $\begin{array}{c}\text { Кормові } \\
\text { буряки }\end{array}$ & $\begin{array}{c}\text { Озима } \\
\text { пшениця, } \\
\text { пожнивні } \\
\text { посіви }\end{array}$ & Рис & $\begin{array}{l}\text { Однорічні } \\
\text { трави }\end{array}$ \\
\hline 5 & Соя & $\begin{array}{c}\text { Кормові } \\
\text { коренеп- } \\
\text { лоди }\end{array}$ & $\begin{array}{c}\text { Озимі або } \\
\text { ярі зер- } \\
\text { нові (аг- } \\
\text { ромеліо- } \\
\text { ративне } \\
\text { поле) } \\
\end{array}$ & $\begin{array}{c}\text { Озима пше- } \\
\text { ниця з після- } \\
\text { жнивним по- } \\
\text { сівом на } \\
\text { корм }\end{array}$ \\
\hline 6 & $\begin{array}{c}\text { Кукурудза } \\
\text { на зерно }\end{array}$ & $\begin{array}{c}\text { Кукурудза } \\
\text { на зерно }\end{array}$ & Рис & $\begin{array}{c}\text { Ячмінь з під- } \\
\text { сівом багато- } \\
\text { річних трав }\end{array}$ \\
\hline 7 & $\begin{array}{c}\text { Кукурудза } \\
\text { на зерно }\end{array}$ & $\begin{array}{c}\text { Кукурудза } \\
\text { на зерно }\end{array}$ & Рис & \\
\hline 8 & $\begin{array}{c}\text { Кукурудза } \\
\text { на силос }\end{array}$ & $\begin{array}{c}\text { Кукурудза } \\
\text { на силос }\end{array}$ & & \\
\hline 9 & $\begin{array}{c}\text { Озима } \\
\text { пшениця + } \\
\text { літній по- } \\
\text { сів люце- } \\
\text { рни }\end{array}$ & $\begin{array}{c}\text { Озимі зла- } \\
\text { ково-бо- } \\
\text { бові сумі- } \\
\text { шки, поукі- } \\
\text { сна куку- } \\
\text { рудза на } \\
\text { силос }\end{array}$ & & \\
\hline 10 & & $\begin{array}{c}\text { Люцерна } \\
\text { під покрив } \\
\text { кукурудзи } \\
\text { на зеле- } \\
\text { ний корм }\end{array}$ & & \\
\hline
\end{tabular}

Так, статтею 20 Закону України «Про землеустрій» визнається обов'язковість землеустрою на землях усіх категорій незалежно від фрорми власності у разі: а) розробки документації із землеустрою щодо організації раціонального використання та охорони земель; д) виявлення порушених земель і земель, що зазнають впливів негативних процесів та проведення заходів щодо їх відновлення чи консервації, рекультивації порушених земель, землювання малопродуктивних угідь, захисту земель від ерозії, підтоплення, заболочення, вторинного засолення, висушення, ущільнення, забруднення промисловими відходами, радіоактивними і хімічними речовинами та інших видів деградації, консервації деградованих і малопродуктивних земель. Водночас пунктом е) статті 25 цього ж закону проекти землеустрою, що забезпечують еколого-економічне обгрунтування сівозміни та впорядкування угідь віднесені до обов'язкової документації із землеустрою. Проте статтею 52 цього ж закону конкретизується, що проекти землеустрою, що забезпечують еколого-економічне обгрунтування сівозміни та впорядкування угідь, розробляються за заявою зекмлевласників чи землекористувачів? Тобто, на підставі укладених договорів між замовниками документації із землеустрою та її розробниками? Себто Верховна Рада України на законодавчому рівні упереджено виключає саму можливість реалізації державної ініціативи зі збереження родючості земель під час землекористування! На підтвердження цього статтею 186 Земельного кодексу України ці проекти не віднесені до категорії тих, які повинні пройти державну експертизу та погодження в наглядових органах??! Аналогічний підхід простежується і в постанові Кабінету Міністрів України від 2.11.2011 року №1134 «Про затвердження Порядку розроблення проектів землеустрою, що забезпечують еколого-економічне обгрунтування сівозміни та впорядкування угідь». Так, частиною 3 зазначеного Порядку встановлено, що ці проекти розробляються на підставі укладеного договору між замовником та його розробником (ці проекти не віднесені до головних державних пріоритетів). У частині 5 вказаного Порядку декларується, що замовником таких проектів може бути сільська, селищна, міська рада або районна, Київська, Севастопольська міська держадміністрація, землевласник, землекористувач. Навіть в урядовому документі прямої дії спостерігається повна безконкретність визначення замовників даної роботи. Кому ж коли, в яких випадках бути замовником і яких саме проектів? Апогеєм недбальства державної влади є частина 9 цього Порядку. В ній головний орган державної виконавчої влади знімає з себе обов'язок нагляду за основним національним багатством країни. При цьому узаконюється вимога з непотрібності державної земельної й екологіч- 
ної експертизи і погодження цих проектів з спеціально уповноваженими органами державного нагляду. Натомість визнається достатність їх затвердження замовником (у т.ч. орендарем)??!

Інакше кажучи, з одного боку Україна статтею 14 Конституції визнає землю основним національним багатством, яке перебуває під особливою охороною держави! Статтею 13 вона від імені Українського народу передає верховну функцію здійснення прав власника землі й інших природних ресурсів органам державної влади та місцевого самоврядування! Статтею 16 основного закону Українська держава зобов'язується постійно забезпечувати екологічну рівновагу на території України та вживати необхідних заходів щодо збереження генофонду Українського народу [17]! 3 іншого ж боку Верховна Рада України у вказаних законах не визнає землю основним національним багатством, виводить її з під особливої охорони держави (державного нагляду) та не дає конкретних важелів органам державної влади і місцевого самоврядування для реалізації верховної функції прав власника землі?!

Висновки й перспективи досліджень. У цій статті проаналізовані правові причини неефективності державного управління і нагляду в Україні за впровадженням орендарями заходів з охорони та раціонального використання земель. Розглянуті підходи органів державної влади до розподілу сільськогосподарських угідь України за формами власності. Встановлено, що в нашій країні $\epsilon$ найбільша частка світових запасів чорноземів, а також вкрай недбале їх використання у складі приватно-пайових земель дрібних землевласників орендарями-землекористувачами. Внаслідок існуючої упередженості земельного законодавства та суцільної недовіри дрібних землевласників до чинної системи оренди землі, сьогодні 12\% усіх сільгоспугідь не здається в оренду та не використовується. В статті розкрито механізм масового пограбування орендодавців-власників приватних паїв і держави в цілому орендарями-землекористувачами, за рахунок штучного заниження розмірів орендної плати та податків до бюджетів різних рівнів, а також існуючої з боку органів державної влади, місцевого самоврядування та державних наглядових органів безмежної підтримки цього кримінального свавілля. Недбальство та масове недотримання природоохоронних вимог орендарями-землекористувачами вже призвело до масової деградації, техногенного забруднення основного національного багатства - земель України, які орендарі не бажають консервувати, рекультивувати та поліпшувати. Законодавчі вимоги щодо дотримання сівозмін, вжиття грунтозахисних заходів, впровадження інвеститцій в землеробство, рослинництво і тваринництво України, орендарями, а також їх покровителями- органами державної влади та місцевого самоврядування повністю ігноруються. Грабіжницькі підходи до сільськогосподарського товарного виробництва висвітлюються в усталеній 70\%-й частці рослинництва. Це в свою чергу означає, що тваринництво занедбане і органічних добрив для землеробства немає, а кожен 4-й га ріллі закислений. В результаті цього середня врожайність українських чорноземів в 2,5 рази нижча, ніж у Великобританії, Франції та Німеччині. Інакше кажучи концентрація земель сільськогосподарського призначення, особливо тих, що належать приватним власникам земельних паїв, в обробітку орендарів вже знищила родючі землі України! Держава ж при цьому не виконує свою головну конституційну роль гаранта збереження основного національного багатства України. 3 огляду на таку катастрофічну ситуацію в сільському господарстві країни і зокрема в землеробстві та рослинництві, вже сьогодні на найвищому рівні державної законодавчої, виконавчої, правоохоронної та судової гілок влади необхідно:

1. Провести комплексні перевірки основної господарської, фрінансової, податкової та природоохоронної (землеохоронної) діяльності орендарів державних, приватних і пайових сільськогосподарських земель з вжиттям вичерпних заходів дисциплінарного, адміністративного та кримінального впливу до порушників чинного законодавства України.

2. Провести одночасний детальний моніторинг (інструментальний контроль, аналіз, прогноз) якісних і кількісних характеристик державних, приватних і пайових земель сільськогосподарського призначення, які перебували в оренді з початку 90-х років. Зробити їх порівняльний аналіз з аналогічними радянськими даними земельного кадастру до 1991 року. У випадку суттєвого погіршення якісних і кількісних характеристик цих грунтів, зобов'язати орендарів компенсувати вартість відновлення їх родючості за власний кошт.

3. 3 метою забезпечення державного продовольчого резерву створити на $25 \%$ державних сільськогосподарських земель України державні підприємства 3 товарного сільськогосподарського виробництва, яким дозволити брати в оренду приватні землі і паї.

4. Вивчити досвід держави Ізраїль щодо ефективності діяльності сільськогосподарських комун (кібуц, мошавів) і запропонувати 6 млн. орендодавців-пайщиків України утворити на добровільній основі комунальні сільськогосподарські підприємства на 21,4 млн. га приватних та пайових земель, з наданням їм пільгових державних кредитів і пільгової оренди виробничих і невиробничих засобів.

5. Підтримати успішні індивідуальні фермерські господарства в питаннях ефективного товарного сільськогосподарського виробництва. 
6. Скорегувати земельне, екологічне, податкове та цивільне законодавство України з запровадженням положень про встановлення орендної плати за використання сільськогосподарських земель не від нормативної грошової оцінки, а від врожайності гектара у певному грунтово-екологічному районі.

7.Оптимізувати співвідношення земельних угідь шляхом законодавчого встановлення та утримання відношення дестабільних фракторів (рілля, сади) до стабільних (природні кормові угіддя, ліси, лісосмуги) на рівні не вище одиниці. 8. До Земельного кодексу України внести статтю по скороченню площі розораних земель України до рівня не вище $40 \%$ та утриманні частки ріллі від площі сільгоспугідь на рівні не вище $50 \%$.

9. Кабінету Міністрів України дати доручення органам виконавчої влади і місцевого самоврядування вивести з інтенсивного використання деградовані, малопродуктивні, техногенно забруднені землі з одночасним укладенням договорів 3 їх власниками про консервацію цих земель методом залуження або заліснення.

10. Верховній Раді України гармонізувати розвиток сільського господарства України за рахунок законодавчого затвердження оптимального співвідношення між обсягами тваринництва і рослинництва в країні.

11. Законодавчій гілці державної влади підвищити рівень ефективності сільського господарства в Україні за рахунок законодавчого встановлення механізму інтенсивного фінансування використання високородючих грунтів і зменшення вкладень в малопродуктивні землі.

12. Впровадити в чинне земельне законодавство екологічно збалансовані методи обробітку грунту.

13. Розробити та впровадити зональні рекомендації з захисту грунтів від вітрової та водної ерозії.

14. Запровадити в Україні систему безперервних наземних та аерокосмічних спостережень за дотриманням орендарями науково-обгрунтованих вимог землеробства, рослинництва і землекористування. У разі їх недотримання дані вказаних досліджень використовувати для нарахування та стягнення збитків, кошти яких спрямовувати на відновлення кількісних і якісних характеристик земель.

15. Доручити профрільним науково-дослідним установам Національної академії аграрних наук України розробити та затвердити в Кабінеті Міністрів України типові для грунтово-екологічних районів науково-обгрунтовані системи землеробства і рослинництва та впровадити їх в якості законодавчих норм.

16. Вилучити в Міністерства економіки, торгівлі та сільського господарства України фрункції державного нагляду (контролю) за використанням й охороною земель та передати їх наново створеному Міністерству державного нагляду за охороною довкілля та природокористуванням України, якому надати статус правоохоронного органу, з виведенням його структурних підрозділів з підпорядкування і координації місцевих органів державної влади та встановлення його підзвітності головному носієві суверенітету - народу України.

\section{Література}

1. Стратегія удосконалення механізму управління в сфрері використання та охорони земель сільськогосподарського призначення державної власності та розпорядження ними, затверджена постановою Кабінету Міністрів України від 07.06.2017 року №413. Режим доступу до ресуpcy: https://zakon.rada.gov.ua/laws/show/4132017-\%D0\%BF

2. http://zemvisnuk.com.ua. Вартість сільськогоспо-дарських земель та їх оренди у країнах Європейського Союзу та Україні (28.03.2018р.)

3. http://umoloda.kiev.ua/number/3277/159/ 120784/. За рік вартість оренди землі в Україні виросла на чверть (21.02.2018p.)

4.www.sknews.net. Вплив мораторію на стан ґрунтів та екології (24.07.2017р.)

5. Гаркавий В.В. Результати роботи рослинницьких галузей сільського господарства України [Електронний ресурс]/В.В. Гаркавий// Економіка і суспільство - 2016. -№2/2016. С. 93-96. Режим доступу до електронного наукового фахового видання: http://economyandsociety.in.ua/index.php/ journal-2/9-articles-2/45-garkavij-v-v.

6. Цилюрик О. Продуктивність науково-обґрунтованих сівозмін Степу [Електронний ресурс]/О. Цилюрик, Л. Десятник// Агробізнес сьогодні -2016. -№1225. Режим доступу до журн.: http://agro-business.com.ua/agro/ekhanizatsiiaapk/item/1225-produktyvnist-naukovoobgruntovanykh-sivozmin-stepu.html.

7.Єщенко В.О. Роль сівозмін у сучасному землеробстві/В.О.Єщенко//Міжвідомчий тематичний науковий збірник «Землеробство». - Київ: ВП «Едельвейс». - 2015. - Вип.1. - С.23-27. http://zemlerobstvo.kiev.ua/.

8. Бойко П. Оптимізація сівозмін: досвід запровадження науково обґрунтованої сівозміни у проекті землеустрою сільгосппідприємства [Електронний ресурс]/ Бойко П., Шевченко І., Коваленко Н.// ТОВ «Торговий дім насіння». - 2018. №422, Режим доступу до ресурсу: http://tdnasinnya.com/ru/statti/biblioteka/422optymizatsia-sivozmin-dosvid-zaprovadzhennianaukovoobgruntovanoi-sivozminy-u-proektizemleustroiu-silhosppidpryiemstva.

9. В.Б. Гройсман. Агропром має становити 20-25\% економіки. http://economics.unian.ua/agro/
Інженерія природокористування, 2020, №4(18), с. 100 - 113

Engineering of nature management, 2020,\#4(18), p. $100-113$ 
10049330-agroprom-maye-stanoviti-20-25-

ukrajinskoji-ekonomiki-groysman.html

10.Кібуц. - Режим доступу до ресурсу: https://uk.m.wikipedia.org/wiki/

11. 30+ графиков и карт, которые доступно объясняют агробизнес Украины. Режим доступа к ресурсу: http://businessviews.com.ua/ru/ekono $\mathrm{my} / \mathrm{id} / 20$-grafikov-i-kart-kotorye-dostupno-objas njajut-agrobiznes-ukrainy-328/

12. Проект Закону України «Про внесення змін до деяких законодавчих актів України щодо обігу земель сільськогосподарського призначення» №2178-10. - Режим доступу до ресурсу: https://w1.c1.rada.gov.ua/pls/zweb2/webproc4_1?p f3511 $=67059$

13.Укрінформ. Держстат порахував скільки українців отримують мінімальну зарплату. - Режим доступу до ресурсу: https://www.ukrinform. ua/rubric-society/2406235-derzstat-porahuvavskilki-ukrainciv-otrimuut-minimalnu-zarplatu.html

14. Пенсійний фонд України. Звіт про розподіл пенсіонерів за розмірами призначених місячних пенсій станом на 01.01.2019p. - Режим доступу: https://www.pfu.gov.ua/387109-zvit-pro-rozpo dil-pensioneriv-za-rozmiramy-pryznachenyh-mi syachnyh-pensij-stanom-na-01-01-2019-forma-5-pf/

15. Сільське господарство України напередодні продовольчої кризи. Режим доступу до ресурсу: http://forbes.net.ua/opinions/1401679-silske-gospodarstvo-ukrajini-naperedodni-prodovolchoyi-krizi.

16. Державна реєстрація договорів оренди землі відтепер доступна онлайн. Режим доступу до ресурсу: https://minjust.gov.ua/news/ministry/ /derjavna-reestratsiya-dogovoriv-orendi-zemli-

vidteper-dostupna-onlayn

17. Конституція України - 254к/96-ВР. Режим доступу до ресурсу: https://zakon.rada.gov.ua/ laws/show/254\%D0\%BA/96-\%D0\%B2\%D1\%80

\section{Reference:}

1. Stratehiia udoskonalennia mekhanizmu upravlinnia $v$ sferi vykorystannia ta okhorony zemel silskohospodarskoho pryznachennia derzhavnoi vlasnosti ta rozporiadzhennia nymy (2017). Ukraine. Available at: https://zakon.rada.gov.ua/laws/show/413-2017-п.

2. Vartist silskohospodarskykh zemel ta yikh orendy u krainakh Yevropeiskoho Soiuzu ta Ukraini (2018). Available at: http://zemvisnuk.com.ua/page/vart-st-zemel-ta-kh-orendi.

3. Sydorenko, O. (2018) Za rik vartist orendy zemli v Ukraini vyrosla na chvert, Ukraina moloda. Available at: http://umoloda.kiev.ua/number/3277 /159/120784/.

4. Vplyv moratoriiu na stan gruntiv ta ekolohii (2017) Suspil'nyj korespondent. Available at: http://www.sknews.net/vplyv-moratoriyu-na-stanhruntiv-ta-ekolohiji/.

5. Harkavyi, V. V. (2016) 'Rezultaty roboty roslynnytskykh haluzei silskoho hospodarstva Ukrainy',
Ekonomika i suspilstvo, (2), pp. 93-96. Available at: http://economyandsociety.in.ua/index.php/ journal2/9-articles-2/45-garkavij-v-v.

6. Tsyliuryk, O. and Desiatnyk, L. (2016) 'Produktyvnist naukovo-obgruntovanykh sivozmin Stepu', Ahrobiznes sohodni, (1225). Available at: http://agro-business.com.ua/agro/ekhanizatsiiaapk/item/1225-produktyvnist-naukovo-obgruntovanykh-sivozmin-stepu.html.

7. leshchenko, V. O. (2015) 'Rol sivozmin u suchasnomu zemlerobstvi', Mizhvidomchyi tematychnyi naukovyi zbirnyk "Zemlerobstvo», (1), pp. 23-27.

8. Boiko, P., Shevchenko, I. and Kovalenko, N. (2018) Optymizatsiia sivozmin: dosvid zaprovadzhennia naukovo obgruntovanoi sivozminy $u$ proekti zemleustroiu silhosppidpryiemstva, Torgovyj dim nasinnja. TOV «Torhovyi dim nasinnia». Available at: http://tdnasinnya.com/ru/statti/biblioteka/422optymizatsia-sivozmin-dosvid-zaprovadzhennianaukovoobgruntovanoi-sivozminy-u-proekti-zemleustroiu-silhosppidpryiemstva.

9. Hroisman, V. B. (2018) Ahroprom maie stanovyty 20-25\% ekonomiky, UNIAN. Available at: http://economics.unian.ua/agro/10049330-agrop rom-maye-stanoviti-20-25-ukrajinskoji-ekonomikigroysman.html.

10. Kibuts (2019). Available at: https://uk.m.wikipedia.org/wiki/Кібуц.

11. 30+ grafikov i kart, kotorye dostupno obyasnyayut agrobiznes Ukrainy (2016). Available at: https://businessviews.com.ua/ru/economy/id/20grafikov-i-kart-kotorye-dostupno-objasnjajut-agrobiznes-ukrainy-328/.

12. Proekt Zakonu Ukrainy «Pro vnesennia zmin do deiakykh zakonodavchykh aktiv Ukrainy shchodo obihu zemel silskohospodarskoho pryznachennia» (no date).

13. Derzhstat porakhuvav skilky ukraintsiv otrymuiut minimalnu zarplatu (2018) Ukrinform. Available at: https://www.ukrinform.ua/rubric-society/2406235-derzstat-porahuvav-skilki-ukrainciv-otrimuut-minimalnu-zarplatu.html.

14. Zvit pro rozpodil pensioneriv za rozmiramy pryznachenykh misiachnykh pensii stanom na 01.01.2019r. (2019) Pensiinyi fond Ukrainy. Available at: https://www.pfu.gov.ua/387109-zvit-pro-rozpodilpensioneriv-za-rozmiramy-pryznachenyh-mis-

yachnyh-pensij-stanom-na-01-01-2019-forma-5-pf/.

15. Silske hospodarstvo Ukrainy naperedodni prodovolchoi kryzy (no date). Available at: http://forbes.net.ua/opinions/1401679-silske-gospodarstvo-ukrajini-naperedodni-prodovolchoyi-krizi.

16. 'Derzhavna reiestratsiia dohovoriv orendy zemli vidteper dostupna onlain' (2020). Available at: https://minjust.gov.ua/news/ministry//derjavnareestratsiya-dogovoriv-orendi-zemli-vidteperdostupna-onlayn.

17. Konstytutsiia Ukrainy - 254k/96-VR (2020). Available at: https://zakon.rada.gov.ua/laws/ show/254k/96-vr 


\title{
Аннотация \\ Совершенствование правовых основ государственного надзора за соблюде- нием арендаторами Украины требований екологоощадного землепользования и охраны земель
}

\author{
А.В. Овчаров, В.М. Власовец
}

Проанализировано состояние землепользования в товарном сельскохозяйственном производстве. Приведены данные существенному ухудшению количественных и качественных характеристик сельскохозяйственных земель. Указано серьезную несовершенство законодательно-правового сопровождения вопросам аренды земель и государственного надзора за правильностью землепользования. Целью настоящей работы является разработка предложений по совершенствованию государственного надзора за выполнением арендаторами требований соберетния плодородия почв, в том числе и за счет внедрения научно обоснованных закононых предложений.

Ключевые слова: государственный надзор (контроль), законодательно-правовое сопровождение, Конституция Украины, действующее законодательство, деградированные земли, гумус, аренда, землевладелец, севооборот, плодородие почв.

\section{Abstract}

\section{Improving the legal framework for state supervision for compliance by tenants of Ukraine with the requirements environmentally friendly land use and land protection}

\section{O.V. Ovcharov, V.M. Vlasovets}

The state of land use in commodity agricultural production is analyzed. The data of significant deterioration of quantitative and qualitative characteristics of agricultural lands are given. The serious imperfection of the legislative and legal support of land lease issues and state supervision over the correctness of land use is noted. The purpose of this work is to develop proposals to improve state supervision over the implementation of tenants' requirements for maintaining soil fertility, including through the introduction of scientifically sound legislative proposals.

Keywords: state supervision (control), legislative and legal support, Constitution of Ukraine, current legislation, degraded lands, humus, rent, landowner, crop rotation, soil fertility.

Бібліографічне посилання/ Bibliography citation: Harvard

Ovcharov, O. V. and Vlasovets, V. M. (2020) 'Improving the legal framework for state supervision for compliance by tenants of Ukraine with the requirements environmentally friendly land use and land protection', Engineering of nature management, (4(18), pp. 100 - 113.

Подано до редакції / Received: 08.11.2020 